\title{
Distance Learning and Administrators Training in Basic Education: The Importance, Principles and Meanings in Contemporaneity
}

\author{
Naura Syria Carapeto Ferreira \\ Tuiuti University of Paraná, Curitiba, Paraná, Brazil \\ Email: nauraf@uol.com.br \\ Received January 2015
}

\begin{abstract}
This article addresses three fundamental elements in contemporaneity for Brazilians and worldwide people: The Distance Learning, the Administrators Training and the Basic Education. It is necessary to understand them within the relation that links them and demonstrates responsibility from the principles and meanings committed with citizen human formation of all the Brazilian and worldwide population. Therefore, I will point at re-signifying those elements in this relation, opening ways to purposeful ideas.
\end{abstract}

\section{Keywords}

Distance Learning, Education, Technology Education, Administrators, Management

\section{Introduction}

The purpose of this article is to contribute to the training of administrators working in basic education, which is the first level of education, in order to stimulate them to have a higher commitment in carrying out research, reinforcing advances in scientific production and the publication of their results.

The Distance Education, the Managers Training and the Basic Education are three key elements in contemporary times for humanity. It is also important the relation among them and the responsibility they utter, according to the principles and meanings committed to citizen human formation of all Brazilians and the world population.

Nowadays, the revisiting of Distance Learning (hereinafter referred to as DL) is not only a reality, but also a necessity. It is fundamental to use it as a powerful tool to provide quality to education, enabling and ensuring true democratization of teaching in order to develop citizenship acquisition.

\section{The Importance of Distance Education as a Teaching Model}

Distance learning training of education administrators must be reinforced and committed with quality education that forms administrators responsible for ensuring the knowledge socialization in the world with powerful 
transformations. For this reason, effective communication is necessary for the student to receive the information with all its complexities and reflect on it.

In Brazil, the specificities of distance education are recognized as a form of education that enables selflearning with the mediation of didactic resources systematically organized, and presented in different media information that can be used alone or combined and transmitted by different media.

The complex and "confusing" modern world does not give place just to metaphors, it also produces the concept, obliging a "rearrangement" of boundaries, since it is characterized by the new technical and scientific environment in which the two explanatory elements are the culture and technique, besides characterizing the economy's globalization and the emergence of a new family of places. The contemporary acceleration-not to mention "violence"- does not escape from this fact. It is more susceptible of being an object of metaphors' construction because we fully live the time of signs, after we have lived the time of gods, the time of the body and the time of machines. The symbols are confusing since they take the place of real things.

The contemporary acceleration imposes new rhythms to the body's displacement and ideas' transportation. However, it also adds a new item to the history, once it is the result of invention trivialization, the premature extinction of mills and their blistering succession. They are overlapped accelerations concomitant to those seen today.

The significant amount of information of discourses, images, film packages and animated cartoons makes things, the objects, the events and the people, meaningless, and it is precisely about the reality's insignificance, about the trivialization process that is the basis of the excess of discourses and images sense that appear in the globalized public space. The very reality is replaced and dissuaded by the meaning proliferation, thereby assenting a pretexted status of a new reality—a reality naturally discursive and imageable [10].

Trivialization means the suppression of distinctive marks; it becomes vulgar [6]. It is a category that dramatically ascends with the intensification process of globalized capitalism under the protection of the Minimum State and the development of technology and media.

In this context, killing and dying, lying, cheating, betrayal, shame, and all forms of human violence broadcasted, so naturally, through the media, are already assimilated and incorporated concepts for all people who have access to such media. However, especially and unfortunately for the children and teenagers, inert in front of the television since a young age, without even yet succeeded in pronounce these terms correctly.

This incorporation of trivialized concepts occurs through media language, socially "forming" the minds and hearts of everyone, especially children, permeating early childhood education with subjects not selected as a priority for their development, but as subjects prioritized by the capital that "urge" to sell and sell more each time. It "cultivates" consumerism of trivialized goods, all of them, completely meaningless, giving them another meaning: the desire to possess and consume "at any price" and in face of this "picture", what is in fact offered? The emptiness! Insecurity! Fear! Anguish! Horror! Losing life’s meaning! Loneliness! What in fact is left for the population, it is the mass production of goods that turns people into things and customize items, altering them and giving other "meanings" to the production intended for consumerism that also needs, in this perspective, to be cultivated.

This triviality of life and death, of "love" and hate, of magnificent and abominable, of wealth and poverty-in its most various and different forms of expression, raw or disguised and under "special effects" of sound, lights and colors - reinforce the thinking of adornment according to which the consolidation process of "half forming", where the concept was poorly apprehended and does not demonstrate that it is a first stage conclusion that must be overcome. In fact, absorbing what has been trivialized is a mortal enemy of formation since it distorts the comprehension of reality, displacing it from the real-concrete and stripping it of its true meaning and significance creating induced feelings within apprehensions.

All the social conditions that establish the formation of losses, each time more inhuman, create the concept essence of "cultural industry" that nowadays reiterates the consolidation of the so-called "virtual reality". It is the "virtual" that becomes "real" replacing "reality" that becomes "virtual". Then leaving ideas, feelings and values of the individuals in their associations with the objective world-their family, friends, work colleagues, neighbors, acquaintances, ideals partners, leisure companions-disaggregating their inner self.

\section{Distance Education Applied in a Specific Context}

In view of the previous discussion, more than ever, it is necessary to make use of the DL which will "reach" homes and institutions carrying the word that teaches, the word that contains principles, the word that stimulates the creation of life, the word of hope that knowledge provides. It is the educator's word, the education adminis- 
trator, responsible for uncovering these contradictions that mask the reality and trivialize life and death.

So this word, this power of knowledge has to be passed on, transmitted, crafted with the conviction's energy that fascinates the hearts and minds of learners. It is this word that will enable reconstruction of life, of society and of the world by making it become fairer and more humane.

Distance Learning procedures have to be aware of its commitments in order to acquire the meaning of an access instrument for knowledge and cultural assets, which should be socialized. This new meaning will imply a new responsibility to the leaders and everyone that work with distance education.

In face of this reality, some challenges are presented as commitments to DL and administrators training. Distance education and administrators training require:

1. being understood as a practice of mediation between content of scientific knowledge, social needs and public policies;

2. being understood as an interpreter and a source of grants for the training, for citizenship;

3. being understood as a source of insights for the development of new policies and new knowledge;

4. being studied and understood as an important feature that enables the professional practice in all areas of education and teaching;

5. being incorporated into training courses for education professionals on the scale of responsibilities attached to them;

6. being incorporated while making collective and responsible decisions, for all educators, as a commitment to develop a top notch education and teaching;

7. assuming, in fact, and collectively, policy, planning, management and assessment of the school's education and teaching;

8. taking the responsibility to develop the abilities, cognitive and behavioral skills, and strategies appropriate to the necessary training for citizenship;

9. developing a social vision, including the understanding of global and local issues;

10. stimulating construction of new spaces of citizenship;

11. accomplishing the organization of educational work, linked to the implementation of democratization of intra- and extra-curricular channels, aiming to break the fragmentation of pedagogical practice;

12. reviewing the autonomy and the role of movements within the school and the organization of work inside the school beyond the corporate and institutional assets;

13. revisiting the conception of society that sustains the fierce individualism that obstructs human development and the development of society, so that we can build a more humane and caring society;

14. rethinking the concept of society that rests on democratic principles of fraternity, solidarity, freedom and social justice;

15. performing an intervention that contributes effectively in the process of human emancipation.

\section{Conclusions}

It is necessary to reframe the Distance Learning based on the principles of interaction, reflection, research, collaboration and knowledge construction, which are essential for any educational modality.

Thus, the Distance Learning assumes the significance of the opportunity to reinvent a commitment to authentic empowerment, a commitment beyond it, instead of being the product of an enlightened forward thinking. The Distance Education thus reveals itself as an emancipatory common sense.

Reframing DL, therefore, it is to commit to human emancipation that will only happen when it is possible to understand the intrinsic relationship that exists between all the new forms of relationships that the complex globalized world has foisted, the education management and the public policies, all over this current globalized society. Thus, distance education will contribute to build another globalization comprised of solidarity, hope and generosity. It is up to the DL the commitment to enable a formation:

that it is based on constitutional principles of freedom and solidarity and entered in all global documents that guarantee the rights of citizens. World citizenship will only be achieved when the theoretical status of training be based on a new global human solidarity ethic that respects differences and ensure a continuum of human training to all living beings until the end of their lives, overcoming the evil in the world established by a hedonistic, competitive and narcissistic individualism; and installing, by solidarity and collective construction, the necessary kindness for the true human development of all mankind. [11] 
As a result, the humanity—composed of all human beings—can regain hope, because

what we want is the opportunity to build a new future cultural structure with the outgrowth of civic virtue, disposition, education of the senses and the mind, civility, politeness, joy, nobility, solidarity, forms of life with dignity, sensitivity to nature - manufactured or preserved — as well as poetry, music, theater, painting and many other beautiful things in life, in the lives of every single people. [7]

Distance learning is nowadays a key issue in administrators training for primary education that are critical and responsible with practices that enable the realization and human emancipation for all.

\section{Acknowledgements}

The author thanks Edson de Lima Rabelo and Debora C. S. Gonçalves for the translation of this paper.

\section{References*}

[1] GAttali, J. (1982) Histoires du temps. Fayard, Paris. [In French].

[2] Dohse, K., Jurgens, U. and Malsch, T. (1985) From Fordism to Toyotism? The Social Organization of the Labor Process in the Japanese Automobile Industry. Politics \& Society, Los Altos, 14. http://dx.doi.org/10.1177/003232928501400201

[3] Ferreira, N.S.C. (1998) Education Technology and the Professional in Brasil: His or Her Formation and the Possibility of Human Culture. In: Tecnologia Educacional [Educational Technology Magazine] (In Portuguese). (26)141.

[4] Ferreira, N.S.C. (1999) Education Technology and the Professional in Brazil: His or Her Formation and the Possibility of Human Culture. In: Bulletin of Science, Technology \& Society, v. 19, n. 3. Sage Science Press, Thousand Oaks, London, New Delhi, 206-209. http://dx.doi.org/10.1177/027046769901900304

[5] Ferreira, N.S.C. (2000) Democratic Management in Education for Human Development: Concepts and Possibilities (In Portuguese). EmAberto. (72)17. Brasília-DF.

[6] Ferreira, N.S.C. (2001) Educational Technology and Management in Education: Between Utopia and Reality. (In Portuguese). In: Tecnologias em educação: Estudos e investigações. Proceedings of the XI Colóquio da Afirse. Universidade de Lisboa, Lisboa.

[7] Ferreira, N.S.C. (2002) Educational Supervision: For a Quality School. (In Portuguese). 3rd Edition, Cortez Editora, São Paulo, 42.

[8] Ferreira, N.S.C. and Aguiar, M.A.S. (2002c) Education Management: Impasses, Perspectives and Commitments. (InPortuguese). 6th Edition, Cortez Editora, São Paulo.

[9] Ferreira, N.S.C. (2002) Teaching and Training Policies: Commitments in Education Management. (In Portuguese). In: Romanowski, J., Martins, P.L.O. and Junqueira, S.R.A., Eds., Conhecimento local e conhecimento universal: Práticas sociais: Aulas, saberes e políticas. Vol. 4. Champagnat, Curitiba.

[10] Ferreira, N.S.C. (2003) Is It Possible to Humanize Education in a Globalized World? Yes, It Is. (In Portuguese). In: Ferreira, N.S.C., Ed., A Gestão da educação na sociedade mundializada: Por uma nova cidadania. DP\&A, Rio de Janeiro.

[11] Ferreira, N.S.C. (2003) The Individualism in Contemporaneity and the Commitments of Education Management. (In Portuguese). In: Tradição, modernidade e as veredas da mestiçagem, 37, Editora da Universidade Eduardo Mondlane-UEM, Maputo/Moçambique.

[12] Ferreira, N.S.C. (2007) Continuing Education and Education Management in the Context of “Globalized Culture”. (In Portuguese). In: Ferreira, N.S.C., Ed., Formação continuada e gestão da educação. 3rd Edition, Cortez Editora, São Paulo.

[13] Ferreira, N.S.C. (2008) Democratic Management in Education: Current Trends, New Challenges. (In Portuguese). 6th Edition, Cortez Editora, São Paulo. http://dx.doi.org/10.1590/S0100-15741999000200013

[14] Ferreira, N.S.C. (2008) Educational Supervision for a Quality School. (In Portuguese). 7th Editon, Cortez Editora, São Paulo.

[15] Ferreira, N.S.C. (2008) Educational Supervision: New Exigencies, New Concepts, and New Meanings. (In Portuguese). In: Rangel, M., Ed., Pedagogical Supervision: Principles and Practices (In Portuguese). 8th Edition, Papirus, Campinas.

[16] Ferreira, N.S.C. and Aguiar, M.A.S. (2008) Guidance and Educational Supervision: Where Is It Coursing? (In Portu-

"Refs. 1-5, 8, 9, 12-18 are not cited in the text. But they are used as basis for reading, once they have some ideas that fit what the author has already published in her previous papers. 
guese). 4th Edition, Papirus, Campinas.

[17] Lojkine, J. (1990) La classeouvriereen mutations. (In Portuguese). Transl. José Paulo Netto. Oficina de Livros, Belo Horizonte.

[18] Saviani, D. (1980) From common sense education to philosophic consciousness. Cortez Editora, São Paulo. 